KS. JÓZEF SZYMAŃSKI* - LUBLIN

\title{
Z DZIEJÓW DUSZPASTERSTWA POLONIJNEGO W SZWAJCARII DO 1935 ROKU
}

Duszpasterstwo polonijne w Szwajcarii sięga XIX w. kiedy corocznie do tego kraju napływało wielu robotników sezonowych. Ich liczbę, do II wojny światowej szacowano na ponad 2 tys. osób ${ }^{1}$. Początkowo, swoistym remedium na ich potrzeby religijne była inicjatywa polskich duchownych pochodzących spod trzech zaborów, a odbywających studia specjalistyczne we Fryburgu Szwajcarskim. Erygowane wówczas przez nich (1902 r.) stowarzyszenie akademickie Jagiellonia, przekształcone na Polonię (3 XII 1918 r.), w ramach Komisariatu Oświatowego zajmowało się m.in. formacją religijną i oświatową polskich robotników. Na jednym z zebrań, 31 XII 1914 r. członkowie stowarzyszenia zdecydowali aby każdy z duszpasterzy odwiedzał swoich podopiecznych regularnie co 2 tyg. Dotąd bowiem, skupiska Polaków usytuowane w pobliżu kościołów parafialnych wizytowano raz w miesiącu. Od stycznia 1915 r. w organizowanie opieki włączył się Patronat Robotniczy. Koegzystencja obu organizacji przetrwała do 1919 r. Dnia 17 VI 1920 r. uchwalono „Statuty pastoryzacji”. Członkowie stowarzyszenia Polonia zobowiązali się wówczas w koloniach robotniczych (10), „zawiadamiać tak pracodawców jak i robotników i proboszczów parafii ich zamieszkania o planowanych wyjazdach z posługą duszpasterską"2.

Do II wojny światowej opiekę duszpasterską nad rodakami zamieszkującymi lub podejmującymi pracę $\mathrm{w}$ tym kraju sprawowali przede wszystkim polscy księża studenci. Duchowni oddelegowani na studia specjalistyczne na Uniwersytet we Fryburgu, łączyli obowiązki naukowe z duszpasterskimi. Za każdym razem informowali oni o podejmowanych przez siebie działaniach duszpasterskich swoich przełożonych diecezjalnych i zakonnych, a później i Księdza Prymasa Polski, odpowiedzialnego za opiekę duszpasterską wśród wychodźstwa polskiego (1931

* ks. Józef Szymański - dr historii Kościoła, adiunkt w Ośrodku Badań nad Polonią i Duszpasterstwem Polonijnym KUL.

${ }^{1}$ Polacy na szerokim świecie, opracował K. Grudziński, Warszawa 1936, s. 34-35.

${ }^{2}$ Ośrodki duszpasterstwa polskiego w Szwajcarii, red. ks. J. Wołczański, Lublin 2000, s. 14. 
r. $)^{3}$. Jedną z pierwszych informacji na ten temat jest pismo ks. Jana Jaroszewicza ${ }^{4}$ z diecezji kieleckiej, aczkolwiek rok wcześniej studia specjalistyczne i opiekę duszpasterską nad rodakami w Szwajcarii podjął już kapłan z tej samej diecezji Józef Łapot ${ }^{5}$. Ks. Jaroszewicz napisał wówczas:

${ }^{3}$ Ks. J. Szymański, Szwajcaria. Duszpasterstwo polonijne, „Encyklopedia Katolicka” red. E. Gigilewicz, 18(2013), k. 240; B. Kołodziej, Opieka duszpasterska nad Polakami za granica 19191938, Poznań 2003, s. 337-338.

${ }^{4}$ Urodził się 27 maja 1903 w Mitawie na Łotwie. Syn Mateusza i Barbary z d. Plechowicz. Tam ukończył szkołę podstawową i rozpoczął gimnazjum. Podczas I wojny światowej rodzinę wysiedlono w głąb Rosji - Tuła, gdzie ukończył gimnazjum. W 1920 został przyjęty do Wyższego Seminarium Duchownego w Kielcach. 11 października 1925 z rąk bpa Augusta Łosińskiego przyjął święcenia kapłańskie. Przez dwa lata pracował jako wikariusz w Staromieściu. W roku akademickim 1927/1928 studiował teologię dogmatyczną na KUL, a od 1928 - we Fryburgu w Szwajcarii. Rozprawę doktorską obronił w 1931 i wrócił do Kielc, gdzie został ojcem duchownym i profesorem teologii dogmatycznej w seminarium. Wykłady prowadził do (przyjęcia sakry biskupiej - 1957). W 1. 1935-1941 był redaktorem „Kieleckiego Przeglądu Diecezjalnego”. W 1938 został wykładowcą apologetyki w nowo powstałym Instytucie Wyższej Kultury Religijnej i asystentem kościelnym Akcji Katolickiej. W 1939 dyrektorem Apostolstwa Modlitwy i Krucjaty Eucharystycznej. Był moderatorem Sodalicji Mariańskiej Panów i delegatem ordynariusza w zarządzie Towarzystwa Szkół Katolickich. W 1939 został rektorem Seminarium Duchownego. Podczas okupacji wykazał się talentem organizacyjnym i rozwagą, co pozwoliło utrzymać wykłady, a nawet przyjmować alumnów z innych diecezji. W 1. 1931-1945 był opiekunem Domu Dziecka św. Tomasza.

W 1945 zrezygnował z funkcji rektora seminarium, zachowując wykłady z teologii dogmatycznej. Z polecenia ordynariusza organizował „Współczesną Ambonę”. 27 września 1949 został wikariuszem generalnym diecezji, i na wypadek nieprzewidzianych okoliczności został wyznaczony przez ordynariusza na rządcę diecezji. 20 stycznia 1951 został aresztowany w kieleckiej Kurii wraz z bpem Cz. Kaczmarkiem i uwięziony w mokotowskim więzieniu. 14 stycznia 1955 został zwolniony z więzienia. Podjął wykłady w seminarium. 10 grudnia 1957 został biskupem sufraganem diecezji kieleckiej. Za zgodą Stolicy Apostolskiej, 13 września 1963 został mianowany przez prymasa Stefana kard. Wyszyńskiego administratorem diecezji kieleckiej. 20 marca 1967 został ordynariuszem diecezji. Uczestniczył w I, III i IV sesji obrad soborowych. Uczestniczył w przygotowaniach i realizacji Roku Jubileuszowego 1975. w diecezji kieleckiej oraz w wydarzeniach związanych z inauguracją pontyfikatu Jana Pawła II w 1978. W diecezji organizował: (m.in. koronację obrazów Matki Bożej Wiślickiej i Smardzowickiej, peregrynację obrazu Matki Bożej Częstochowskiej po diecezji kieleckiej i in.); przygotował jubileusz 800-lecia kolegiaty i katedry kieleckiej oraz 250lecia Seminarium. Zmarł 17 kwietnia 1980.

Ks. biskup Jaroszewicz ordynariuszem diecezji kieleckiej, „Duszpasterz Polski Zagranicą” 18(1967) z. 4(73), s. 454-455; Śp. ks. bp Jan Jaroszewicz Ordynariusz Kielecki, „Duszpasterz Polski Zagranicą” 31(1980) z. 3(136), s. 442; Ks. bp E. Materski, Jaroszewicz Jan, w: Słownik Polskich Teologów Katolickich 1918-1981, red. ks. L. Grzebień SJ, t. 5, Warszawa 1983, s. 586-591.

${ }^{5}$ Urodził się 3 marca 1903 w Grabowcu k. Chmielnika. Syn Antoniego i Józefy z d. Dutkiewicz. Wykształcenie elementarne otrzymał w 1. 1910-1913 najpierw w domu, później w szkole początkowej w Piotrkowicach. W 1922 uzyskał świadectwo dojrzałości w Państwowym Gimnazjum im. Jana Śniadeckiego w Kielcach. W tym samym roku wstąpił do Seminarium Duchownego w Kielcach. 6 czerwca 1926 z rąk bpa Augusta Łosińskiego przyjął święcenia kapłańskie. W roku szkolnym 1926/1927 pracował jako wikariusz w Wiślicy. Od jesieni 1927 odbywał studia specjalistyczne z teologii moralnej we Fryburgu Szwajcarskim, uwieńczone doktoratem 20 lipca 1931. W 1. 19311939, po powrocie do Kielc, pracował jako prefekt, najpierw w szkole powszechnej im. Konarskie- 
„W związku z objęciem przez J.E. Ks. Prymasa opieki nad wychodźstwem polskim pragnąłbym przesłać dane o emigracji polskiej w Szwajcarii. Jako b. kierownik duszpasterstwa Polaków zamieszkałych w Szwajcarii (pracowałem na tej placówce od r. 1928 do 1931) mógłbym dostarczyć szczegółowych informacji o stanie religijnym naszego wychodźstwa oraz o akcji duszpasterskiej, która po wyjeździe moim w lipcu b.r. została przerwana"6.

Jej kontynuowania podjął się ks. Franciszek Jaworski ${ }^{7} \mathrm{z}$ diecezji włocławskiej. W piśmie skierowanym do Kancelarii Prymasa informował on, że:

„Praca w tym roku jest może wyjątkowo trudna. Jestem bowiem tylko sam i do tego nie domagam na zdrowiu. Praca zaś do wykonania jest ta sama, owszem nawet rozszerzona do jednej stacji klimatycznej - Leysin, w której jest sporo Polaków katolików, a których bardzo pożądanem byłoby też od czasu do czasu odwiedzić. Razem więc w tym roku jest obsługiwane jedenaście miejscowości. Obecnie liczą one około 230 dusz. (...) Najwięcej kapłan jest potrzebny latem. (...) Nadto są jeszcze drobniejsze cztery placówki, które się zupełnie pomija z powodu braku kapłanów i odpowiednio większych funduszy. Dotąd od początku roku akademickiego zrobiłem 20 wyjazdów".

go, a od 1932 w szkole powszechnej Państwowego Seminarium Nauczycielskiego. Ponadto w 1933/1934 był prefektem Żeńskiego Gimnazjum im. A. Mickiewicza, później zaś kolejno dwóch państwowych gimnazjów męskich, im. St. Żeromskiego i im. J. Śniadeckiego. Lipiec i sierpień 1939 spędził wśród wychodźstwa polskiego w Szwajcarii i Belgii. W czasie wojny uczył nadal na kompletach tajnego nauczania. W 1942 został profesorem etyki i katechetyki w Wyższym Seminarium Duchownym w Kielcach, i jednocześnie jego wicerektorem. Tę ostatnią funkcję spełniał do 1945; profesorem był do 1949. W 1. 1945-1948 był diecezjalnym wizytatorem nauczania religii.

Od 17 października 1949, na zaproszenie Administratora Apostolskiego Diecezji Warmińskiej ks. Teodora Bunscha, został rektorem i podjął się organizacji Warmińskiego Seminarium Duchownego w Olsztynie - Hosianum, w którym jednocześnie był profesorem etyki, katechetyki, teologii moralnej. Funkcję rektora pełnił do 13 sierpnia 1958. 1 sierpnia 1951 został kanonikiem reaktywowanej Kapituły Katedralnej we Fromborku. 4 grudnia 1958 został proboszczem parafii św. Jakuba w Olsztynie i dziekanem olsztyńskim. We wrześniu 1959 zrezygnował z obu tych stanowisk, a także z funkcji profesora teologii moralnej. Przez kilka lat redagował Warmińskie Wiadomości Diecezjalne. Ostatnie lata życia spędził w domu Księży Emerytów w Kielcach. Tam, zmarł 19 lipca 1962. Został pochowany na cmentarzu w rodzinnej parafii Piotrkowice.

Ks. A. Zuberbier, Łapot Józef, w: Słownik Polskich Teologów Katolickich 1918-1981, red. ks. L. Grzebień SJ, t. 6, Warszawa 1983, s. 367-368; Tenże, Wspomnienia pośmiertne. Józef Łapot, „Kielecki Przegląd Diecezjalny” 40(1964), nr 6, s. 283-286; A. Kopiczko, Duchowieństwo katolickie diecezji warmińskiej w latach 1945-1992, cz. 2: Stownik, Olsztyn 2007, s. 173-174.

${ }^{6}$ Archiwum Archidiecezjalne w Gnieźnie (dalej: AAG), Archiwum Prymasa Polski (dalej: APP), Akta Protektora Wychodźstwa Polskiego (dalej: APWP), Szwajcaria, Dział III/110, Ks. J. Jaroszewicz, Do Kancelarji J. Em. Ks. Prymasa Polski, 20. IX. 1931.

${ }^{7}$ AAG, APP, APWP, Szwajcaria, Dział III/110, Karol Radoński Biskup Włocławski, Eminencjo!, Włocławek 28 października $1931 \mathrm{r}$.

${ }^{8}$ AAG, APP, APWP, Szwajcaria, Dział III/110, Ks. Franciszek Jaworski, Do Prześwietnej Kancelarji Prymasa Polski w Poznaniu, Fribourg dn. 8 czerwca 1932 r. 
Zaangażowanie swoich kapłanów aprobował bp włocławski ${ }^{9}$, informując prymasa że wyraża zgodę na podjęcie opieki duszpasterskiej wśród Polaków przez kolejnego duchownego swojej diecezji - ks. Leona Andrzejewskiego ${ }^{10}$, oddelegowanego na studia specjalistyczne do Fryburga. Tenże, kapłan 16 listopada 1932 r. poinformował prymasa, ,że w bieżącym roku akademickim opiekę duszpasterską

\footnotetext{
${ }^{9}$ AAG, APP, APWP, Szwajcaria, Dział III/110, Karol Radoński Biskup Włocławski, Do Kancelarji Prymasa Polski w Poznaniu, Włocławek, dn. 2 grudnia 1932 r.

${ }^{10}$ Urodził się 21 stycznia 1907 w Woli Nakonowskiej k. Kowala. Syn Jakuba i Marianny z d. Włodarczyk. Początkowo naukę pobierał w szkole, w majątku Wola Nakonowska. Po wybuchu I wojny światowej przez 2 lata uczył się w domu. W 1916 rozpoczął naukę w Szkole Powszechnej w Nakonowie. Po ukończeniu 13 lat wstąpił do 4 klasy Gimnazjum im. J. Długosza we Włocławku. W 1922 przeniósł się do Liceum im. Piusa X we Włocławku. Po złożeniu egzaminu maturalnego w 1925, podjął studia filozoficzno-teologiczne w Wyższym Seminarium Duchownym we Włocławku. Święcenia kapłańskie z rąk bpa Karola Mieczysława Radońskiego przyjął 22 czerwca 1930. Jako neoprezbiter od 14 lipca podjął obowiązki duszpasterskie w Opatówku k. Kalisza, gdzie tymczasowo pełnił również obowiązki administratora parafii. W październiku 1932 rozpoczął studia specjalistyczne we Fryburgu. Za zgodą Prymasa Polski pełnił równocześnie posługę duszpasterską wśród Polonii szwajcarskiej. Po uzyskaniu doktoratu z teologii (28 lipca 1935) powrócił do kraju i przez kilka tygodni (od 1 do 20 września) był wikariuszem w Kole, a następnie w Sieradzu (do 1 września 1938). Od tegoż roku kontynuował studia specjalistyczne na Uniwersytecie Gregoriańskim w Rzymie. W maju 1939 nostryfikował swoją pracę doktorską na Katolickim Uniwersytecie Lubelskim i został mianowany profesorem teologii dogmatycznej w Wyższym Seminarium Duchownym we Włocławku (od 1 września).

7 listopada 1939 we Włocławku został aresztowany przez Niemców. Przebywał w obozie karnym w Szczeglinie oraz w obozach koncentracyjnych: Sachsenhausen (od 29 sierpnia 1940) i Dachau (od 14 grudnia 1940, nr obozowy 22 663). Po wyzwoleniu, pracował w duszpasterstwie polskim we Francji (Paris, Soissons). 2 maja 1946 powrócił do Polski i podjął obowiązki wykładowcy w Wyższym Seminarium Duchownym we Włocławku. Z powodu braku katechetów prowadził też zajęcia $\mathrm{z}$ nauki religii w gimnazjum przy fabryce Bohrna we Włocławku. 28 lutego 1948 został wicerektorem seminarium, a 15 czerwca 1952 rektorem. Był też promotorem sprawiedliwości w sądzie biskupim. W 1. 1952-1961 pełnił funkcję przewodniczącego Diecezjalnej Komisji Artystycznej. 19 grudnia 1949 został kanonikiem gremialnym kapituły katedralnej, w 1962 szambelanem, a 16 listopada 1963 prałatem domowym Jego Świątobliwości. Przymuszony przez władze diecezjalną, 23 marca 1965 zrezygnował z funkcji rektora seminarium i wyjechał do Częstochowy. Życie zakończył 29 sierpnia 1965. Pochowany został na cmentarzu we Włocławku.

Archiwum Diecezji Włocławskiej. Dział Personalny. Akta ks. Andrzejewski Leon 1907-1965. bez. sygn.; Archiwum Archidiecezjalne w Gnieźnie, Archiwum Prymasa Polski, Akta Protektora Wychodźstwa Polskiego, Szwajcaria, Dział III/110; K. Rulka, Andrzejewski Leon, w: Stownik Polskich Teologów Katolickich 1918-1981, red. ks. L. Grzebień SJ, t. 5, Warszawa 1983, s. 49-50; Ks. S. Szczeblewski, Ks. Leon Andrzejewski, „Kronika Diecezji Włocławskiej” 48(1965), s. 287-288; Ks. J. Dębiński, Andrzejewski Leon, w: Włocławski Słownik Biograficzny, red. S. Kunikowski, t. III, Włocławek 2005, s. 2-3; Materiały do dziejów Polskiej Misji Katolickiej we Francji. Zeszyt XVIII. Duchowieństwo polskie we Francji od 1922 r. Prezentacja stanu badań - katalog, O. B. Panek OC, Paris 1996, s. 15; E. Weiler, Die Geistlichen in Dachau sowie in anderen Konzentrationslagern und in Gefängnissen, Mödling 1971, s. 107; J. Szymański, Duszpasterze Poloniii i Polaków za granicą. Stownik biograficzny, t. 2, Lublin 2011, s. 7-8.
} 
nad wychodźcami polskimi w Szwajcarii sprawują ks. Jan Cygan ${ }^{11}$ kapłan diecezji kieleckiej i ks. Leon Andrzejewski z diecezji włocławskiej, obaj studenci Uniwersytetu we Fryburgu, jako jedyni księża - Polacy w Szwajcarii" ${ }^{12}$. Obaj duchowni otrzymali zgodę swoich przełożonych: Leon Andrzejewski - bpa włocławskiego ${ }^{13}$ i Jan Cygan - Kurii Biskupiej w Kielcach ${ }^{14}$.

Posługa duszpasterska kapłanów polskich była cały czas monitorowana przez prof. Uniwersytetu we Fryburgu Edwarda Crosa, miejscowego działacza polonijnego. W piśmie do Kancelarii Prymasa Polski zwracając uwagę na konieczność kontynuowania opieki duszpasterskiej nad Polakami w tym kraju, napisał:

„Mam zaszczyt zwrócić się do Przewielebnych Księży w sprawie, którą w ogólnych zarysach, jako delegat Polaków ze Szwajcarii na zeszłoroczny Zjazd Polaków z Zagranicy, przedstawiłem w gmachu Sejmu R. P. J. W. Delegatom Kurii Prymasowskiej. Jest to sprawa pierwszorzędnej wagi dla Polaków - katolików zamieszkujących Szwajcarię, a polega ona na konieczności posiadania na terenie tutejszym kapłana - Polaka, mogącego zajmować się pastoryzacją kolonii naszych, zwłaszcza robotniczych, rozsianych po kraju. Dotychczas omijaliśmy trudnościdziękitemu,żeduchowninasi,przebywającynastudiach poświęcalizofiarnością, godną gorącego uznania i wdzięczności, czas odpoczynku niedzielnego pracy duszpasterskiej wśród Rodaków. Wobec tego, że ostatni z księży naszych, kształcących się we Fryburgu, ks. dr Leon Andrzejewski, który w latach ostatnich opiekował się naszymi koloniami, w miesiącu bieżącym Szwajcarię definitywnie opuści, grozi nam pozostanie bez opieki duszpasterskiej, co w wypadku naszych robotników, nie znających języka obcego, stanie się wyjątkowo poważnym problemem"15.

W reakcji na powyższe pismo Kancelaria Prymasa Polski 1 października 1932 r. poprosiła rektora Arcybiskupiego Seminarium Duchownego w Poznaniu ks. Kazimierza Kowalskiego by „w doborze uniwersytetów zagranicznych do których wysyła się Księży na wyższe studia filozoficzno-teologiczne, uwzględnić również Uniwersytet we Fryburgu Szwajcarskim. Ksiądz student mógłby pełnić także pomocniczą akcję duszpasterską dla nielicznej kolonii robotników polskich

${ }^{11}$ D. Krześniak Firlej, Księża prefekci diecezji kieleckiej 1918-1939, Kielce 2001, s. 53, 70, 111, $118,123-124,142,145,153,155,171$. Pełnił obowiązki wikariusza w Pacanowie. Od sierpnia $1931 \mathrm{r}$. był nauczycielem religii w szkole koedukacyjnej w Stopnicy. „W 1932 r. rozpoczął studia uniwersyteckie we Fryburgu, lecz z powodu choroby po kilku miesiącach przerwał naukę i powrócił do kraju". Następnie był prefektem szkół powszechnych w Bodzentynie, a od 1936 prefektem gimnazjum męskiego w Olkuszu. Od drugiego semestru r. szk. 1938/1939 był prefektem Państwowego Gimnazjum im. S. Żeromskiego w Kielcach. W 1. 1947-1961 proboszczem parfii Góry.

${ }^{12}$ AAG, APP, APWP, Szwajcaria, Dział III/110, Ks. Leon Andrzejewski, Do Prześwietnej Kancelarji Prymasowskiej w Poznaniu, 16 listopada 1932 r.

${ }^{13}$ AAG, APP, APWP, Szwajcaria, Dział III/110, Karol Radoński Biskup Włocławski, Do Kancelarji Prymasa Polski w Poznaniu, Włocławek, dn. 2 grudnia1932 r.

${ }^{14}$ AAG, APP, APWP, Szwajcaria, Dział III/110, Kurja Biskupia Kielce, Do Prześwietnej Kancelarji Prymasa Polski w Poznaniu, 5 grudnia 1932 r.

${ }^{15}$ AAG, APP, APWP, Szwajcaria, Dział III/110, Dr Edward Cros /profesor Uniwersytetu Fryburskiego/ Fryburg, W. Kancelaria Jego Eminencji Kardynała - Prymasa Polski, Poznań, Fryburg / Szwajcaria/, 7, Rue Chaillet, dn. 28 czerwca 1935 r. 
w Szwajcarii"16. Jak dowiadujemy się jednak z pisma Kurii Biskupiej w Lublinie, ,już w sierpniu rb. udał się na dalsze studia do Fryburga w Szwajcarii kapłan naszej diecezji ks. dr Karol Konopka ${ }^{17}$, który zwrócił się z prośbą o polecenie go w Kancelarii Prymasa do pracy duszpasterskiej wśród wychodźstwa polskiego". $\mathrm{Na}$ co otrzymał stosowną zgodę władz kościelnych ${ }^{18}$.

Pełniejszej oceny stanu i sytuacji duszpasterstwa polonijnego w Szwajcarii,

${ }^{16}$ AAG, APP, APWP, Szwajcaria, Dział III/110, Ks. H. Zborowski, Przewielebny Ks. Rektor Dr Kazimierz Kowalski, Rektor Arcyb. Seminarium Duchownego w miejscu, 1 października 1935 r. Na marginesie pisma uwaga: Przygotować odpis miejsc nakreślonych dla Opieki.

${ }_{17}$ Urodził się 10 listopada 1901 w Szczecynie k. Janowa Lubelskiego. Syn Macieja i Katarzyny z d. Pakuła. Szkołę powszechną ukończył w rodzinnej wsi, gimnazjum w Janowie Lubelskim. 1 września 1922 wstąpił do Wyższego Seminarium Duchownego w Lublinie. Święcenia kapłańskie z rąk bpa Mariana Fulmana przyjął 19 czerwca 1927 w katedrze lubelskiej. Po studiach w lubelskim seminarium duchownym rozpoczął studia doktoranckie na Wydziale Teologii Katolickiego Uniwersytetu Lubelskiego, gdzie 13 października 1931 uzyskał dyplom doktora teologii. Od 31 października 1931 pełnił obowiązki wikariusza i prefekta w parafii pw. NMP w Chełmie Lubelskim. 10 sierpnia 1935 został zwolniony z obowiązków duszpasterskich i skierowany na dalsze studia specjalistyczne do Fryburga w Szwajcarii. Za zgodą Prymasa Polski pełnił równocześnie posługę duszpasterską wśród Polonii szwajcarskiej. Tamże 25 lipca 1937 uzyskał drugi stopień doktorski w zakresie filozofii i slawistyki. Po powrocie do Polski, od 24 sierpnia tegoż roku podjął obowiązki dydaktyczne i duszpasterskie jako wykładowca teologii moralnej i ojciec duchowny seminarium lubelskiego. Wykładał również teologię duchowości i liturgikę. 4 października 1937 został Diecezjalnym Dyrektorem Sekretariatu Generalnego Dzieł Misyjnych Diecezji Lubelskiej. Podczas okupacji, czasowo, 12 października 1940 został administratorem parafii Zagłoba. 18 kwietnia 1943 mianowany sędzią sądu biskupiego pierwszej instancji. Współorganizował i prowadził Seminarium Duchowne w Krężnicy (od kwietnia 1945 w Lublinie). Od 1946 prowadził zajęcia zlecone na KUL z teologii ascetycznej i mistycznej oraz liturgii. Był dyrektorem diecezjalnym Unii Apostolskiej Kleru. 18 września 1959 przeszedł na emeryturę. 2 listopada 1966 został ojcem duchownym diecezji. Był kanonikiem kapituły katedralnej lubelskiej, prałatem scholastykiem (1959), prałatem kustoszem (od 16 czerwca 1968). Zmarł 31 grudnia 1969. Został pochowany w Lublinie na cmentarzu przy ul. Lipowej.

Archiwum Archidiecezjalne w Gnieźnie, Archiwum Prymasa Polski, Akta Protektora Wychodźstwa Polskiego, Szwajcaria, Dział III/110; Archiwum Archidiecezjalne w Lublinie. Akta osobowe Rep. 60 II b K 134, Ks. Konopka Karol; Archiwum Uniwersyteckie Katolickiego Uniwersytetu Lubelskiego. Referat personalny. Wydział Teologii. Akta osobowe studentów. Ks. Konopka Karol 1927-1931, [1935], Referat personalny. Wydział Teologii. Akta osobowe pracowników. Ks. Konopka Karol 1948-1960. A. 327; M. Skrzypek, Teolog, norwidysta, ojciec duchowny. Ksiadz Karol Konopka (1901-1969), w: W duchu i prawdzie. Wybrane sylwetki Kościoła lubelskiego (18052005), red. ks. H. Misztal, Lublin 2005, s. 417-422; Tenże, Ks. prat. dr Karol Konopka jako teolog, slawista i norwidysta. Wspomnienie w 100 rocznicę urodzin oraz 32 rocznicę śmierci, „Wiadomości Archidiecezji Lubelskiej” 1 (2002), s. 198-204; S. Młynarczyk, Śp. ks. prałat dr Karol Konopka (1901-1969), emeryt, b. Ojciec Duchowny Seminarium Duchownego Lubelskiego, „Wiadomości Diecezji Lubelskiej” 1-3(1979), s. 59-66; Ks. F. Stopniak, Konopka Karol, w: Stownik Polskich Teologów Katolickich 1918-1981, red. ks. L. Grzebień SJ, t. 6, Warszawa 1983, s. 128-129; J. Starnawski, Zapomniany norwidysta, „Studia Norwidiana”, 3-4 (1985-1986), s. 235-241; Szymański, Duszpaterstwo Polonii i Polaków, t. 2, s. 101-102.

${ }^{18}$ AAG, APP, APWP, Szwajcaria, Dział III/110, Kurja Biskupia w Lublinie, Do Kancelarji Prymasa Polski w Poznaniu, 30 października 1935 r. 
jeszcze tegoż samego roku dokonał ks. Kazimierz Michalski ${ }^{19}$. Jak zaznaczył w piśmie do Kancelarii Prymasa Polski, w porozumieniu z Wydziałem Duszpasterstwa Zagranicznego tejże kancelarii, połączył swój wyjazd wakacyjny z objazdem duszpasterskim placówek polskich wychodźców w Szwajcarii. Swoje

${ }^{19}$ Urodził się 18 sierpnia 1898 w Gnieźnie. Syn Stanisława i Antoniny z d. Wawrzyniak. Ze względu na miejsce zamieszkania i trwającą wojnę w 1917, po zdaniu matury został wcielony do wojska niemieckiego, gdzie swoją służbę wypełniał m.in. jako tłumacz języka rosyjskiego przy sztabie armii I Korpusu w Rostowie nad Donem. Po zakończeniu I wojny światowej i demobilizacji armii niemieckiej, rozpoczął studia teologiczne we Wrocławiu. Od 1919 kontynuował je w Poznaniu. Święcenia kapłańskie z rąk ks. kard. Edmunda Dalbora przyjął 17 grudnia 1922. Posługę kapłańską jako wikariusz pełnił kolejno w Wolsztynie, Trzemesznie i Wągrowcu. Od 1926 był kolejno prefektem i nauczycielem gimnazjów w Lesznie, następnie w Poznaniu. Angażował się w działalność Akcji Katolickiej, a szczególnie w Katolickie Stowarzyszenie Młodzieży Męskiej. W 1932 został wybrany na sekretarza generalnego, a następnie na asystenta kościelnego tegoż stowarzyszenia na teren obu archidiecezji. Od 30 marca 1933 pełnił obowiązki duszpasterskie w Kostrzynie, a 18 lipca otrzymał w administrację parafię w Czerlejnie.

W 1939, został dyrektorem Archidiecezjalnego Instytutu Akcji Katolickiej w Poznaniu. Stanowisko objął w pierwszy dzień II wojny światowej. Po wybuchu wojny został kapelanem wojskowym i uczestniczył w walkach nad Bzurą. 9 listopada 1939 został aresztowany przez Gestapo i wywieziony do klasztoru w Kazimierzu Biskupim, a stamtąd 24 maja 1940 do Dachau, 8 sierpnia został przeniesiony do Gusen, skąd 8 grudnia powrócił do Dachau (nr obozowy 22 112). Poddawany był eksperymentom medycznym.

Po powrocie z obozu kilka miesięcy spędził w Poznaniu. 22 października 1945 objął parafię św. Jadwigi w Zielonej Górze. Zorganizował przedszkola (jedno w domu parafialnym, drugie przy ul. Kościelnej); działające przez kilka następnych lat ognisko parafialne dla młodzieży. 12 czerwca 1946 został dziekanem dekanatu zielonogórskiego. W listopadzie 1947 władze uznały, że całokształt działalności jest ,,antyspołeczny i szkodliwy dla narodu polskiego”. 13 lutego 1950 został aresztowany i przewieziony do więzienia w Poznaniu, które opuścił 29 kwietnia 1950. Za zorganizowanie procesji w dzień Bożego Ciała 1952, został ukarany grzywną. 22 sierpnia 1953 został zatrzymany przez UB i zmuszony do opuszczenia parafii, wymeldowany bez swojej zgody z Zielonej Góry. Zatrzymał się w parafii farnej w Poznaniu. Na skutek „odwilży” w grudniu w 1956 powrócił do Zielonej Góry. Nie zmienił swojego nastawienia do władz, które 15 kwietnia 1960 oficjalnie wystąpiły do kurii gorzowskiej o usunięcie go z Zielonej Góry. Żądanie ponowiono w maju. 17 grudnia 1960 złożył rezygnację i przeszedł na emeryturę. Zamieszkał w parafii św. Wawrzyńca w Poznaniu. Należał do grona konsultorów diecezjalnych. Pełnił także funkcję obrońcy węzła małżeńskiego i sędziego prosynodalnego. Zmarł w Poznaniu 11 lutego 1975, gdzie został pochowany. 13 marca 2010 został pochowany w grobowcu dla zasłużonych kapłanów przy zielonogórskiej konkatedrze.

Ks. D. Śmierzchalski-Wachocz, Obrońca Domu Katolickiego w Zielonej Górze Ks. Kazimierz Michalski (1898-1975), „Nasz Dziennik”, 8-9 maja 2010 r. nr 106 (3732); Weiler, Die Geistlichen in Dachau, s. 453; Ks. M. Banaszak, Michalski Kazimierz, w: Słownik Polskich Teologów Katolickich 1918-1981, red. L. Grzebień SJ, t. 6, Warszawa 1983, s. 463; Konflikt o Dom Katolicki w Zielonej Górze w dniu 30 maja 1960 roku w świetle dokumentów, red. T. Dzwonkowski i in., Poznań 2006, s. 5-6, 8-27, 35, 47-51, 53-58, 60, 62-63, 66-70, 72-75, 77-78, 80, 87-88, 92-93, 98, 100-101, 104, 114, 117-118, 124-125, 129-130, 132-135, 137, 139-142, 144-149, 152-154, 156, 158-159, 162, 166-170, 186, 188-189, 195, 198-203, 205-215, 218-219, 221-224, 229-233, 260-267, 272-274, 276-280, 284-286, 290, 294-295, 302-303, 309, 313-314, 316-318, 323-326, 334, 340-344, 346-347, $352-$ $353,364,370,373,387-390,400-401,403,406,409-410,413,433-436,439$, 442-445. 
spostrzeżenia zawarł w sprawozdaniu przytoczonym poniżej: ${ }^{20}$

W publikacji tekstu dokonano niezbędnego uwspółcześnienia ortografii i interpunkcji,główniezastępującdużeliterymałymi.Zachowanooryginalnystyliskładnię.

Dokument oryginalny w formie maszynopisu, przechowywany jest w Archiwum Archidiecezjalnym w Gnieźnie, Archiwum Prymasa Polski, Akta Protektora Wychodźstwa Polskiego, Szwajcaria, Dział III/110, Ks. Kazimierz Michalski, Sprawozdanie z objazdu duszpasterskiego w Szwajcarii, Vidi 27. IX. 35, k. 1-3.

$* * * *$

Sprawozdanie

Vidi 27. IX. 35

z objazdu duszpasterskiego

w Szwajcarii

KANCELARIA PRYMASA POLSKI

Wpł. 27 WRZE. 1935

L.DZ. 3665

\section{Eminencjo!}

W porozumieniu z Wydziałem Duszpasterstwa Zagranicznego Kancelarii Waszej Eminencji połączyłem z swoim wyjazdem wakacyjnym objazd duszpasterski placówek polskich wychodźców w Szwajcarii, z którego przedkładam następujące sprawozdanie.

Ogólne warunki. Liczebnie kolonie polskie w Szwajcarii są obecnie bardzo słabe z powodu ograniczeń wjazdu i pobytu, jakie stosuje rząd szwajcarski ze względu na bezrobocie w kraju. Polskie kolonie robotnicze koncentrują się:

1/ W okolicy jeziora Neuchâtel w miejscowości Yverdon, Payerne i Avenches - razem około 20 osób.

2/ W Grand Lancy na przedmieściu Genewy - około 20 robotnic.

3/ Theiingen pod Schaffausen - około 15 robotników.

Gospodarcze położenie robotników polskich jest dość ciężkie, gdyż otrzymują oni po 3 - 3,50 fr. szw. dziennie i deputat w ziemniakach, co przy drożyźnie szwajcarskiej starczy bardzo skromnie na opędzenie potrzeb życiowych. Robotnice otrzymują po $50-60 \mathrm{fr}$. szw. miesięcznie i wolne utrzymanie. Warunki pracy są trudne, ponieważ chlebodawcy wyzyskują robotnika polskiego wiedząc, że rząd szwajcarski z łaski jeszcze daje tymczasowo możność zarobkowania. W tych warunkach ani robotnicy, ani władze konsularne nie ośmielają się wnosić protestu. Większość robotników sezonowych będzie prawdopodobnie z końcem roku musiała wracać do kraju.

${ }^{20}$ AAG, APP, APWP, Szwajcaria, Dział III/110, Ks. Kazimierz Michalski, Sprawozdanie z objazdu duszpasterskiego w Szwajcarji, 27 IX 1935. 
Poza robotnikami istnieją ugrupowania polskich sfer urzędniczych /poselstwa i delegacji polskiej/ studentów i przemysłowców. Ogólna liczba Polaków ${ }^{21}$ - katolików dochodzi do 200 osób, podczas gdy obywateli polskich /z polskim paszportem/ znajduje się w Szwajcarii około 5 000. Są to prawie wyłącznie Żydzi.

W tych warunkach jest opieka religijna nad garstką Polaków w Szwajcarii bardzo ważnym zagadnieniem, tak ze względów religijnych, jak narodowych i państwowych.

Stosunek władz. - Władza kościelna /Ordynariat we Fryburgu/ odnosi się bardzo przychylnie do akcji duszpasterskiej wśród wychodźstwa polskiego i udzieliło mi wszystkich uprawnień. Władze świeckie /konsularne - polskie/ również popierają wszelkie poczynania kapłanów polskich, aby uchronić wychodźców przed wpływami żydowskimi i komunistycznymi.

Stosunki wśród społeczeństwa polskiego w Szwajcarii. - Wśród sfer robotniczych panuje miłość i harmonia. Wśród sfer inteligentniejszych nie ma należytego współżycia i harmonii, a szczególnie w Genewie. Przyczyniają się do tego po części różnice partyjno-polityczne, a także działalność pewnej osoby na terenie Genewy, co do której przedkładam Waszej Eminencji osobne sprawozdanie.

Jeżelichodziostosuneksferinteligentnych dosferrobotniczych, tonależyzuznaniem podkreślić, że na terenie Szwajcarii jest kilka osób, które bardzo troskliwie zajmują się wychodźstwem robotniczym w duchu katolickim, tak w dziedzinie religijnej, jak oświatowej i zarobkowej. Do nich należy na pierwszym miejscu p. Jadwiga Romer /urzędniczka Ligi Narodów/ Genčve, 11 Rue Levrier, a także dr Edward Cros /profesor Uniwersytetu Fryburskiego/ Fryburg, 7 Rue Chaillet.

Stosunek do duszpasterza polskiego. - Tak sfery inteligentne, jak też w szczególności robotnicy, odnoszą się do kapłana polskiego z wielką życzliwością i zaufaniem. Z nabożeństw polskich i sakramentów św. korzystają z okazji przyjazdu kapłana polskiego przeważnie sfery robotnicze.

Czynności duszpasterskie. - Teren działalności duszpasterskiej musiałem wpierw przygotować drogą korespondencji, przez co nastąpiło pewne opóźnienie. Odwiedziłem dwa zgrupowania wychodźców w okolicy jeziora Neuchâtel /w Yverdon zgromadzili się robotnicy z Yverdon, Payerne i Avenches/ i w Grand Lancy pod Genewą oraz w samej Genewie. W Yverdon odbyło się łącznie z nabożeństwem polskim zebranie Związku Robotników Polskich "Jedność", na którym był również obecny wicekonsul Adolf Zakrzewski z Berna. Muszę również pod-

${ }^{21} \mathrm{Na}$ terenie Szwajcarii, w 1926 r. według oficjalnych statystyk, przebywało „obywateli polskich 2250, zaliczonych do ludności stałej, i 800 osób do ludności przejezdnej oraz 60 osób robotników sezonowych. Pod względem wyznaniowym emigrację szwajcarską identyfikowano: 18\% chrześcijan i 82\% izraelitów. Największe skupienia Polaków zamieszkiwały w kantonie genewskim - 674 osoby, lozańskim - 493 i neuchatelskim - 240 osób. Ludność przyjezdna rekrutowała się przeważnie ze studentów izraelitów, studiujących w Genewie, Bernie i Zurychu, oraz kleryków i księży, studiujących teologię i filozofię we Fryburgu, młodzieży kształcącej się w szkołach średnich w okolicach Lozanny". Zob. Wychodztwo polskie w poszczególnych krajach. Materiały opracowane na podstawie sprawozdań konsularnych przez Referat Emigracyjny w Wydziale Administracyjno-Paszportowym Departamentu Konsularnego Ministerstwa Spraw Zagranicznych (kwiecień 1926), Warszawa 1926, s. 163. 
kreślić, że robotnice polskie w Grand Lancy mają w tamtejszym proboszczu Montillerie oddanego i życzliwego opiekuna. Mówi on z wielkim uznaniem o prowadzeniu się i pobożności Polek, które w parafii jego - wśród otoczenia kalwińskiego - są wzorem dla wszystkich. Jest to szczególną zasługą p. Jadwigi Romer.

Sprawa duszpasterstwa na przyszłość. - Dotychczas pełnił dorywczo obowiązki duszpasterskie wśród wychodźców ksiądz Andrzejewski z diecezji włocławskiej, który odbywał studia we Fryburgu. Obecnie wrócił on po ukończonych studiach do Polski, a we Fryburgu studiują tylko klerycy z diecezji polskich.

Wychodźstwo polskie w Szwajcarii jest Waszej Eminencji bardzo wdzięczne za pamięć i dotychczasową troskę o nich i składa Waszej Eminencji wyrazy głębokiego hołdu i przyrzeczenia, że chcą trwać przy swej wierze i polskości. Zaniepokojeni, czy i w następnym roku będą mieli kapłana - Polaka wśród siebie, zanoszą do Waszej Eminencji gorącą prośbę, by przysłał księdza na studia, któryby był równocześnie duszpasterzem polskiego wychodźstwa.

Załącznik.

Z wyrazami najgłębszej czci uniżony

Ks. Kazimierz Michalski

THE HISTORY OF THE POLISH CHAPLAINCY IN SWITZERLAND TO 1935

\begin{abstract}
Summary
Until World War II pastoral care of compatriots living and working in Switzerland was provided, first of all, by Polish priests students. Clerics sent to study at the University of Freiburg, combined academic duties with pastoral ones. Each time they informed their diocesan or monastic superiors, and later the Primate of Poland about their pastoral activities. The assessment of the status and situation of Polish chaplaincy in Switzerland was presented by Rev. Kazimierz Michalski in the report included in this paper.
\end{abstract}

